Royal Society for the fiscal year 1964-65 totalled $£ 251,000$ compared with $£ 220,000$ in $1963-64$, of which $£ 100,000$ were for scientific investigations, $£ 45,600$ for research professorships, and $£ 95,400$ for international research and scientific congresses. Brief report on researches are appended, including lists of publications, from the research professors and Research Fellows.

\section{European Launcher Development Organization}

IN a written answer in the House of Commons on February 3, the Minister of Aviation, Mr. R. Jenkins, stated that a conference, attended by all the Member States of the European Launcher Development Organization, met in Paris during January 19-21, to review the activities of the organization and to examine proposals for its future work. The cost of completing the first programmed launcher, based on conventional techniques and with a limited operating capacity, would be higher than the original estimate, and a working group had been set up to consider the feasibility of using the technical results already achieved and the experience acquired by the Organization to develop an advanced launching system making use of the most modern techniques. The system would continue to use Blue Streak as the first stage, and the Conference would be convened again later this year to review progress. Britain's part in the European Space Research Organization was the responsibility of the Secretary of State for Education and Science.

\section{Science Research Council}

IN a written reply to a question in the House of Commons on Fobruary 4, Mr. A. Crosland, the Secretary of State for Education and Science, announced that a Science Research Council would be constituted after the enactment of the Science and Technology Bill which is now before Parliament. The Council, under Sir Harry Melville's chairmanship, would consist of: Lord Halsbury; Dr. A. Caress, diroctor of research, Imperial Chemical Industries, Ltd.; Dr. D. G. Christopherson, vice-chancellor and warden of the University of Durham; Dr. S. C. Curran, vice-chancollor of the University of Strathclyde, Glasgow; Prof. G. C. Drew, professor of psychology in University College, London; Prof. M. R. Gavin, professor of electronic engineering in University College of North Wales, Bangor; Sir Ewart Jones, Waynflete professor of chemistry in the University of Oxford; Sir Bernard Lovell, professor of radio astronomy in the University of Manchester and director of Jodrell Bank Experimental Station; Prof. K. Mather, professor of genetics in the University of Birmingham and vice-chancellor-elect of the University of Southampton; Prof. C. F. Powell, Henry Overbon Wills professor of physics in the University of Bristol; Prof. J. E. Smith, professor of zoology in Queen Mary Collego, University of London, and director-elect of Marine Laboratory, Plymouth.

Committee on Manpower Resources for Science and Technology

IN reply to a question by Mr. J. Tinn in the House of Commons on February 4 concerning the arrangements for the continuation of the work formerly performed by the Committie on Scientific Manpower, Mr. A. Crosland stated that the Committee would be known as the Committee on Manpower Resources for Science and Technology. The Committee had now boon re-appointed and the members were: Sir Willis Jackson, professor of electrical engineering, Imperial College of Science and Technology (chairman); Sir Leon Bagrit, chairman and managing director, Elliot-Automation, Ltd.; Prof. J. G. Ball, professor of physical metallurgy, Imperial College of Science and Technology; Mr. G. S. Bosworth, diroctor of Group Personnel Services, the Fnglish Electric Company, Ltd.; Mr. S. L. Bragg, chief scientist in the Aero Engine Division of Rolls Royce, Ltd.; Dr. E. F. Brookman, managing director of the Paints Division, Imperial
Chemical Industries, Ltd.; Lord Brown of Machrihamish, chairman of the Glacier Metal Co., Ltd.; Dr. S. G. Hooker, technical director (Aero) of Bristol Siddeley Engines, Ltd.; Dr. F. E. Jones, managing director of Mullard, Ltd.; Prof. C. A. Moser, professor of social statistics, School of Economics and Political Science in the University of London; Prof. L. Rosenhead, professor of appliod mathematics in the University of Liverpool; Prof. J. R. N. Stone, Leak professor of finance and accounting in the University of Cambridge; Sir Peter Venables, principal of the College of Advanced Technology, Birmingham; Mr. L. T. Wright, general secretary of the Amalgamated Weavers Association. Members from Government Departments: Mr. H. E. Bishop, Central Statistical Office; Mr. G. B. Blaker, Department of Education and Seience; Mr. R. H. W. Bullock, Ministry of Technology; Mr. R. C. Griffiths, University Grants Committee; Mr. F. Jones, Ministry of Economic Affairs; Mr. F. Pickford, Ministry of Labour; Mr. W. G. Pottinger, Scottish Office; Mr. J. K. Thompson, Ministry of Overseas Development. The Committee would report its findings to the Secretary of State for Education and Science, and the Minister of Technology.

\section{Grants to Universities and Colleges in Britain}

IN a written answer in the House of Commons on February 1, Mr. A. Crosland stated that since the settlement of the grants in aid of the recurrent expenditure of universities and colleges in Britain for the last three years of the quinquennium ending on July 31, 1967, was adjusted in February 1964 to take account of the acceptance of the Robbins Committee's proposals for immediate expansion, supplementary grants had been approved for the increases in academic salaries approved on the recommendation of the National Incomes Commission and for a further increase in the intake of medical students. The present level of grants had been reviewed following advice from the University Grants Committee, and, to assist the universities to meet the objectives of the Robbins Report, in view of increased costs since 1963, the grants for these three academic years would be increased by $£ 5.8$ million, bringing the total estimated recurrent provision, excluding rates, to $£ 86.3$ million in $1964-65$; $£ 99.3$ million in $1965-66$; and $£ 109 \cdot 8$ million in $1966-67$, or about $£ 295$ million in all.

\section{The University of Aston in Birmingham}

The College of Advanced Technology, Birmingham, which is shortly to submit a petition to the Queen in Council for the grant of a Charter as a now technological University, has agreed to request that the title of the new University be "The University of Aston in Birmingham". The matter of an appropriate title has been under discussion for some time, and the title now suggested has been agreed on by the Governing Body of the College after considering many views, including the results of questionnaires to members of staff. The College grew up in the City of Birmingham, and was run by the Corporation for many years until 1962, when an independent Governing Body was set up. The name now suggested will carry with it something of the history of the institution, and also reflects the fact that it is the intention of those rosponsible for the new University that it should remain on its present site near the centre of the City. It has already been announced that the Chancellordesignate of the new University is Lord Nelson of Stafford. The first Pro-Chancellor will be Mr. J. A. Hunt, chairman of the Board of Governors of the College, who for many years has been connected with further education, and education for commerce and industry. Mr. Hunt is director and general manager of the Hymatic Engineering Co., Ltd., in Redditch, and a director of other companies, as well as a member of many regional and national bodies connected with education, commerce and manage- 